\title{
\begin{tabular}{lll}
\hline ANAS Transactions & Earth Sciences & $2 / 2020$
\end{tabular}
}

Theory and practice of oil and gas fields development

http://www.journalesgia.com

\section{CURRENT STATE AND PROSPECTS FOR THE DEVELOPMENT OF SMART FIELD TECHNOLOGIES (GENERAL REVIEW)}

\author{
Isayev R.A. \\ SOCAR-AQS LLC \\ 10, A. Rajabli-2 str.,Baku, AZ1075, Azerbaijan:risayev@socar-aqs.com
}

Keywords: smart field, information support, mathematical support and software, organizational support, decision-making
Summary. This article provides a brief analysis of the current state of the problem of creating the scientific foundations for the "smart field" concept which is considered as a system. It is noted that the objectives according to this concept are accomplished in four stages. Using the experience of various companies as examples, the results of this system functioning are given. In terms of support, the "Smart Field" system mainly includes three subsystems: information support, mathematical support and software, and organizational support. The obtained information allows you to make operational and correct management decisions, to ensure effective planning and implementation of geological and technical measures, repair and maintenance of equipment. In general, the focal point in the system is decision-making. At the same time, decisions are made under conditions of uncertainty. The development of the scientific foundations of the system therefore also includes the analysis of uncertainties which can be of a various nature.

It is proposed to form a list of specialists required for the modern oil and gas industry. It is noted that the most in demand are competencies that can be applied in any industry. To solve successfully problems related to "smart fields" it is necessary to combine the efforts of specialists of different profiles, namely: geologists, geophysicists, developers, drillers, programmers, professionals in economic and mathematical modeling, creation of automated control systems and decision-making.

(C) 2020 Earth Science Division, Azerbaijan National Academy of Sciences. All rights reserved.

\section{Introduction}

Making the right technological decisions in the development of oil and gas fields, drilling oil and gas wells and in general the tasks of oil field practice require a detailed study of geological sections, obtaining the necessary information about the section, the properties of hydrocarbons, used technical means and technologies. This problem is even more complicated in the case of a small and remote field. In this regard, when making decisions, it is also necessary to take this circumstance into account. Another problem that has to be encountered in finding solutions is related to the amount of information. In this case information plays a huge role and the lack of information makes it difficult to make the right decisions. This may be due to both a lack of data and an excess of data. It should be noted that the absence (or lack) of the necessary information, its untimely receipt negatively affects the efficiency and adequacy of decisions made during field development and well drilling. When trying to analyze such infor- mation technologists face great difficulties. This circumstance has contributed recently to the search for various ways of obtaining and analyzing information. Processing such a volume of data in order to obtain important information necessitates the development and application of modern tools, in particular artificial intelligence methods and methods that allow working in conditions of insufficient information. Technologies developed in recent years have taken a strong place in all spheres of human activity. The development of this direction is clearly noticeable in the activities of various oil and gas companies of the world that are involved in decision-making. The correctness of decisions to a significant extent also depends on the conditions: at the same time the same solutions that are effective in some conditions may be ineffective in others, in other words: the decision of some of them can only aggravate others. So for example, the wrong choice of oil recovery enhancement technologies can give a small increase to production but at the same time significantly in- 
crease capital or operating costs (for example, drilling additional production wells) or in drilling wells: bits selected based on the desire to ensure high speed may be ineffective for economic reasons. In this case a problem arises with uncertainty. This circumstance can also be encountered during modeling, etc. Under the mentioned conditions oil and gas producing companies need a management system that, using the information coming from the fields efficiently, will allow for constant monitoring of indicators and make decisions regarding investments in the development and implementation of new technologies, taking into account uncertainties. Judging by the preliminary results obtained, such a system which has recently attracted the attention of oil industry workers and called the "smart field" can take the oil and gas industry to a new level in the near future, ensuring the efficiency of companies in difficult geological conditions.

\section{Brief analysis of the general concepts and current state of «Smart Field» systems}

First of all, it is necessary to find out what these "smart fields" or as they are otherwise called "intelligent fields" actually are, what basic properties (attributes, features) characterize them and what technologies form the basis of this system. The methodology of the above system, the components and equipment for the operation of "smart" wells and fields have been developed and used with great success in various regions of the world including the USA, the North Sea, West Africa, the Middle East, Brunei, Australia, Russia, Kazakhstan, etc. Analysis of the «Smart Field» system development status and world experience in their creation (Smart wells ROGTEC, 2014; Redutskiy, 2017) allows uncovering the essence and clarifying some definitions necessary for understanding the methodology for constructing these systems.

In particular the author (Redutskiy, 2017) summarizes the above review with the following definition: "smart" solution (in the narrow sense of the term, for the oil industry) is an approach to reservoir management which includes two closely related aspects: optimization of the life cycle based on research of development and production operations and determination of strategic, tactical and operational goals; advanced instrumentation as a leading technology for accurate monitoring and control of operations.

In order to study the concept of a smart field and identify the development trends a literature review was conducted and the main characteristic features of process solutions within the framework of this concept were determined. As examples of the technology introduction in various operations
(Ерёмин, 2008; Smart wells - ROGTEC, 2014; Воробьев и др., 2018; Эфендиев, 2019; Лопухов, 2017; Rossi et al., 2000), the results of the activities of various engineering companies were analyzed.

Wells and fields are not made "smart" by the new technology, but by a successful combination of the existing advanced technologies, including wireless data transmission, remote sensors, remote control mechanisms and robotics. Remote sensors reproduce a real-time picture of what is happening downhole. The maximum effect from the operation of downhole sensors is achieved through the use of control systems that allow performing certain actions when downhole conditions change (Smart wells - ROGTEC, 2014; Воробьев и др., 2018; Интеллектуальная скважина, 2015). According to the authors of work (Воробьев и др., 2018), “...the core of the smart oil and gas reservoir management system is a hardware and software complex capable of analyzing a rather large volume of field information received in real time, resulting in quick identification of any deviations from the design (specified) parameters, formation of effective options for control actions and development of optimal technical, process and logistic solutions for them, and in some cases independent implementation of these solutions (still with the permission of the operator)".

So, a "smart oil and gas field" means a system (or class of systems) of automatic control of well drilling, oil and gas production operations, providing for continuous optimization of these processes, which requires integrated field modeling and drilling and production control modeling (Еремин, 2008; Демарчук, 2014a). In various literary sources and companies different analogues of the term "smart field" are used: digital oilfield, intelligent field, instrumented field, field of the future, integrated field operations control, etc. A specific concept of this term is the concept of a smart well. At present it is quite difficult to construct a fully automatic control of oil and gas production due to complexity and uncertainty in individual elements of an integrated model, in particular geological models. The term "intellectual deposit" is based, being strongly connected, on the concept of an intelligent control system, the elements of which are control methods using various methods of artificial intelligence. Modern categories of smart oil and gas technologies may include "smart" wells; new methods of studying well operation; new ways to obtain and use information; reservoir models, which are called "intelligent" in the framework of the system in question; well drilling process control; technologies for regulating the development of oil and gas fields; unconventional methods for classification of geological features, exploration, diagnostics, well drilling, field development, etc. 
Based on the above we can conclude that creation of the scientific foundations of the "smart field" concept is relevant and meets modern requirements of oilfield theory and practice.

\section{3. "Smart Field" system: basic principles}

In terms of support the «Smart Field» system mainly includes three subsystems (Fig. 1). One of the main subsystems is an information support system. The large-scale introduction of SF technologies will require a qualitative change in the management system and organization at oil and gas enterprises. A "smart field" as an integrated system includes subsystems for the production and use of information, modeling (forecasting) of well drilling and field development processes and decision-making. As can be seen from the diagram the output of this information system is the information on the basis of which decisions are made. To build a smart system for monitoring the hydrocarbon production process, it is necessary, as noted by specialists, to create an automated system for receiving and using information, as well as its processing, analysis and storage. The baseline information for this represents a set of parameters characterizing both the characteristics of the geological section, the condition of drilling and production equipment, and the technology and process indicators (Efendiyev, Piriverdiyev, 2018).

Using this data, the control system, based on models and decision-making algorithms, calculates the technical and technological parameters that are used to optimize the well drilling and oil production processes. The information obtained thus allows making operational and correct management decisions, ensuring effective planning and implementation of well intervention activities, and equipment repairs and maintenance.

In general, as can be seen from the diagram, the focal point in the system is decision-making. At the same time decisions are made under conditions of uncertainty. When developing the scientific foundations of the system it is therefore necessary to analyze uncertainties which can be of a various nature (Efendiyev, Piriverdiyev, 2018).

Mathematical support and software are a combination of mathematical methods, models, algorithms and programs for implementing the goals and objectives of the system, as well as for normal functioning of the hardware complex and decisionmaking. Mathematical support means include: tools for modeling field development processes; typical modeling and decision-making algorithms; methods of mathematical programming, mathematical statistics, theories of reliability, fuzzy sets, etc. A wide range of theoretical, experimental and field studies are considered in the analysis allows identifying the characteristic features of the smart field solutions taken in the management of technological processes of well drilling and field development. In this regard a number of works are devoted to the classification of objects, because this problem is the basis in solving many problems. In recent works the problems of classifying geological features to assess the degree of hydrocarbon recovery difficulty, as well as the problems associated with well drilling are thus proposed to be solved using various mathematical methods (Efendiyev et al., 2016; Akhmetov et al., 2018; Efendiyev et al., 2018; Efendiyev et al., 2019; Bello et al., 2015) (statistical, hard, fuzzy cluster analysis). These works consider and analyze examples of successful application of artificial intelligence methods in the oil and gas industry, namely, in well drilling, indicating the results of application against the background of the trend existing in the industry, show the ways of using fuzzy clustering method and demonstrate the possibilities of using modern methods for classification of challenged hydrocarbon fields. They also provide a brief history and review the works on using artificial intelligence and its capabilities. It is noted that artificial intelligence methods were first used in the 70-80s of the last century to interpret well $\log s$, to diagnose the condition of drill bits using neural networks, to make decisions in drilling and also to create a smart interface of a reservoir simulation program. In one of the works (Bello et al., 2015), it is proposed to use artificial intelligence to solve various problems of the oil and gas industry, including seismic pattern analysis, reservoir characterization, prediction of petrophysical characteristics (permeability and porosity), decision-making in general and many others. To date, artificial intelligence methods have been successfully applied in the evaluation and use of reservoir characteristics (Cuddy, Glover, 2002). A number of works are devoted to the use of fuzzy logic, neural networks, genetic algorithms in solving oilfield practical problems (Bello et al., 2015; Cuddy, Glover, 2002). Even in the past researchers in the sphere of natural sciences noticed that many, at first glance, random events are accompanied by certain patterns. In the eighteenth century scientists revealed a regularity in the change of any observation around its average value. Such patterns or distributions were approximated by continuous curves called "curves of normal distribution of errors" and assigned to the laws of probability (Cuddy, Glover, 2002; Efendiyev et al., 2019). Normal distribution is completely determined by the two parameters: average value and variance. In this case the variance depends on hidden, inherent parameters and measurement error. Variance about the average value is one of the main 
conditions causing fuzziness, and in connection with this the authors of another work (Cuddy, Glover, 2002) attempted to justify why this parameter characterizes fuzziness and requires the use of fuzzy logic.

In general, the analysis shows that solving process modeling problems is significantly hampered by the presence of uncertainty associated with the use of both random and fuzzy variables. In (Cuddy, Glover, 2002; Efendiyev et al., 2019) the difference between random and fuzzy values is shown. It is noted that fuzzy variables may be preferable in case of insufficient statistical data and related information necessary for more accurate and reliable estimates.

Studies in the field of optimal decisionmaking should also be noted. Using mathematical methods, artificial intelligence methods for decision-making in oilfield practice (optimization of drilling and production processes, management of field development process, etc.) is thus aimed at providing decision-makers in the field with accurate and correct information about different stages of well drilling and field development, eliminating (minimizing) the effect of human factor, which repeatedly led to errors.

For several decades, researchers have been using optimization models and methods to gain insight into the planning and control of well drilling and field development. All of them together constitute the basis of the mathematical support of the "smart field" systems.

Organizational support is a set of methods and tools governing the interaction of workers with technical means and among themselves in the process of developing and implementing an information system (Fig. 1). Organizational support is created according to the results of preliminary study of organization functioning at the stage of project development and before. In the diagram shown in the figure according to a generalization of literature data, the functions implemented using organizational support are given.

The main objectives of constructing (improving) a «Smart Field» system, due to the goal set for the conditions under consideration, are roughly as follows: analysis of world experience in the practical use of the «Smart Field» system; analysis of the current state of equipment and technology used in the oil and gas complex under consideration and justification of the feasibility of introducing the «Smart Field» system in oil and gas fields; methodology of the «Smart Field» system; justification of the nature of the required information, data collection and processing; design of well construction (classification of a section by drillability, prediction of pressure characteristics, construction of a drilling model, prediction of the required density of a drilling fluid, selection of bits, justification and selection of cement mortar formulations, accident and risk assessment, etc.); classification of fields with hard-torecover reserves and assessment of the degree of difficulty of oil recovery; analysis of the information received; decision-making when choosing oil fields for the priority implementation of the "Smart Field" system; assessment of «Smart Field» system implementation project economic efficiency through the example of a specific oilfield. One of the important problems among the above which have been attracting researchers' attention recently is the problem of classifying fields with hard-to-recover reserves and assessing the degree of difficulty of oil recovery, as well as classifying and predicting the characteristics of geological sections (Akhmetov et al., 2018). Thus, for successful construction of the «Smart Field» system it is necessary to use a clear methodology, set the objectives and apply modern analysis and decision-making methods which are the main ones.

In the work (Kyrnaev et al., 2017) key areas of the "smart field" concept were identified, integrated implementation of which allows increasing the reliability of calculations and evaluating the effectiveness of implementing the operational «Smart Field» system. These results clearly show the wide possibilities of using the implemented systems and great potential for achieving quantitative results, such as reducing the nonproductive time while drilling wells, daily downtime of the well stock and monthly losses in oil production. At the same time the synergistic effect allows minimizing the risk of additional operating expenditures without compromising process and environmental safety.

The results presented in the work (Kyrnaev et al., 2017) make it possible not only to improve qualitatively the methodological understanding of the «Smart Field» system which is very important for the modern oil industry, but also to increase the efficiency of well drilling process control and reservoir management by accumulating, analyzing and generalization successful cases with the results of testing approaches to intellectualization of fields useful for "benchmarking", i.e. comparative analysis based on reference indicators (in other words, it is a process of determining, understanding and adapting the existing examples of efficient company functioning).

In the process of analyzing the works related to the development of the "Smart Field" systems and their methodology, the work (Temizel et al., 2019) provides information about the past and the present of the smart oil field concept and its dynamics, about the methods and methodological approaches that it uses and applies, about technical problems in appli- 
cation, as well as the problems of oil and gas industry professionals regarding the use of those or other technologies as a whole. This article (Temizel et al., 2019) discusses in detail the history of smart/intelligent development of oil fields, the types of technologies currently used in it, details the technologies used in other industries and provides an overview of works in this area. This review takes into account the reliability, applicability and additional benefits that these technologies bring to different types of fields in modern economic conditions. Real practical applications are illustrated through examples in different parts of the world, where problems, advantages and disadvantages that lead to conclusions about the criteria for the use of smart technologies in a particular area are discussed and summarized. Judging by the work performed to date, at the initial stage the smart field concept has established itself as a promising area and has become widely used in oil and gas fields around the world.

In general the work performed allows creating the «Smart Field» system which can be implemented in four stages, namely (Эфендиев, 2019): at the first stage data is collected and systematized, which is carried out both online and offline by receiving data using various systems - telemechanics, mud logging, data on operation of downhole pumping equipment, etc. At this stage the collected data is also processed using statistical method, after which the received information is uploaded to the corporate database.

The second stage involves analysis of the information. This includes well history review and comparison with operation period indicators, analysis of emergencies, their prevention measures, efficiency of protection measures used, etc. (Забродин и Бортников, 2018). The third stage covers decision-making; development (improvement) of measures for further optimization of drilling and production processes. This stage is the most timeconsuming as it requires an integrated approach to decision-making, modeling and predictive assessment. The fourth stage includes assessment of erroneous decision risk and technological and economic efficiency.

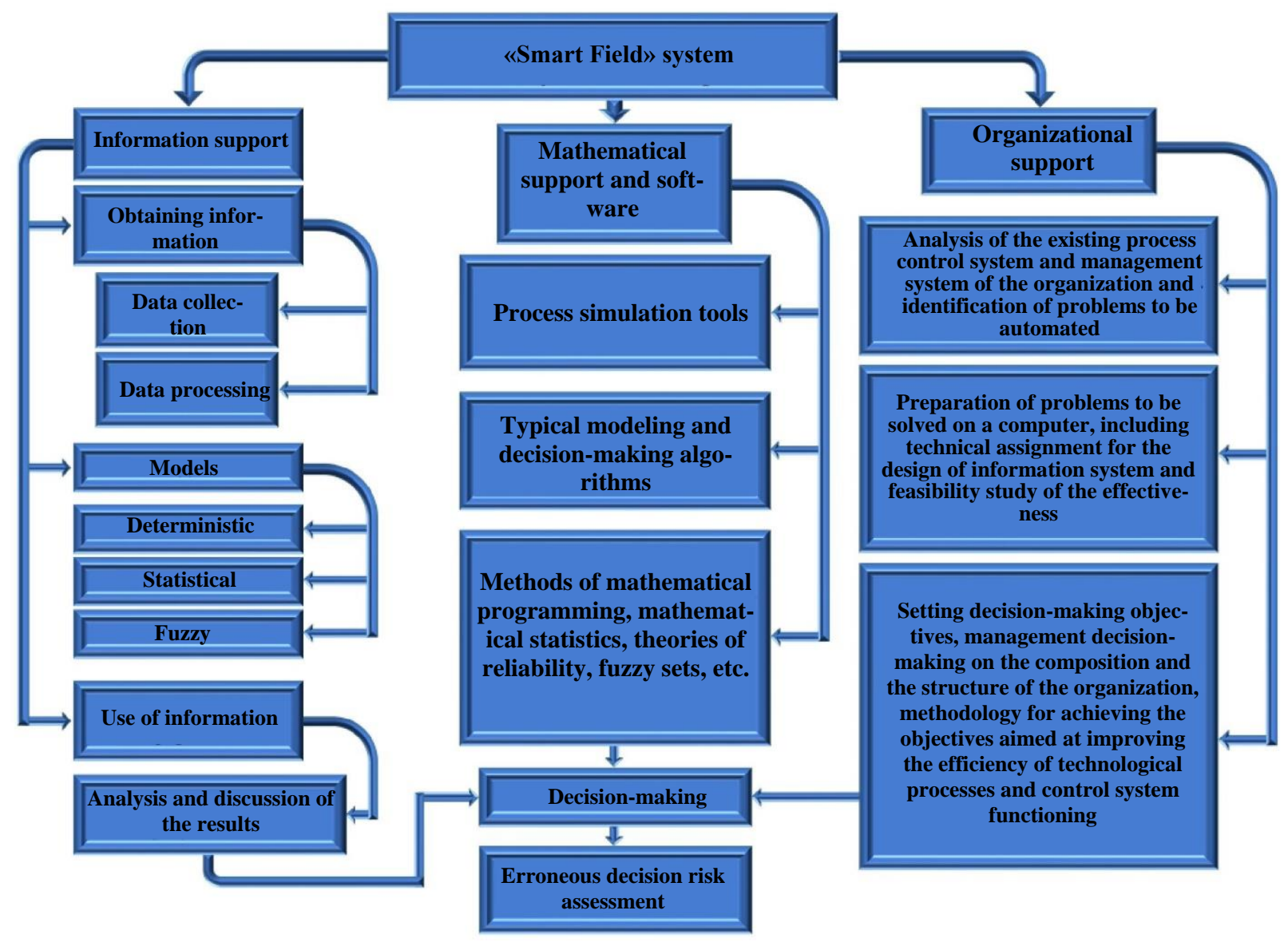

Fig. 1. «Smart Field» system support diagram 
In the literature along with the principles of construction much attention is paid to the practical application of intelligent systems and the results of their functioning in various oil-producing regions of the world are presented. In light of the aforementioned it is necessary to analyze the results obtained in the framework of the experience of using these systems by various companies.

Some results indicate lower operating costs, reduction in operating expenditures (which is very difficult to calculate accurately), reduction in power costs of up to about $25 \%$, according to various sources. As independent experts predict, with the development of smart technologies it will be possible to increase global oil recovery by $30-50 \%$, or even by $60-70 \%$ with the transition to nextgeneration technologies. Some companies are already successfully mastering smart technologies in practice; however, this generally refers to individual components rather than an integrated system.

For example, you should pay attention to the experience of Russian companies. Samotlorneftegaz OJSC has been developing the "smart field" concept for several years. Another leader in the sphere of smart technologies is Tatneft OJSC (Демарчук, 2014b). Extensive experience in implementation of individual elements of "smart" systems has been accumulated by LUKOIL Group, including geological and hydrodynamic modeling, smart well completion and the introduction of smart well control stations (Демарчук, 2014b). In general according to (Козлова, Пигарев, 2018) in Russia in 2018 there are more than 40 projects of smart fields, the total production of which is 140 million tons or $27 \%$ of the total volume in the country.

In Kazakhstan an automated oil and gas field control system has been developed to achieve maximum efficiency by integrating separate systems into a single integrated information system. In 2016 a project was launched on the basis of Uaz field, the introduction of which allowed reducing electric power consumption by $33 \%$ and specific well workover costs by $25 \%$. EmbaMunayGas introduced digital technologies in the Prorvinskoye field group in 2017, in Zhanatalap and East Makat in 2018 and in East Moldabek in 2019. Data processing and information analysis algorithms were automated according to procedures developed by Embamunaygas. All information goes to the head office. Data collection from the field allows you to quickly respond to deviations in the performance of wells and analyze data. According to Kazakhstan experts in the near future it is planned to increase the introduction of these technologies in other fields of KazMunayGas (https://neftegaz.ru/news/politics/202118-kazakhstanrazvivaet-proekt-tsifrovoe-mestorozhdenie/, 2018) and by 2022 their number may exceed 10 .
As an example of remote monitoring and data collection from oil wells, the work (Лопухов, 2017) provides experience of Terra Ferma, a system integrator engaged in remote video monitoring and data collection at wellheads located in the Rocky Mountains area of the State of Colorado. Each wellhead system consists of automatic data recording, monitoring and control devices connected by cellular channels to central server and control center several miles away. Event-triggered data logs and full reports should be accessible through wired and wireless Ethernet network from smartphones, tablet computers and laptops, allowing operators to access control center data wherever they are (Лопухов, 2017). In these systems communication networks connect the company, remote personnel, field information and technological processes into a single system around the world. As an example, the BP system, with a length of $1280 \mathrm{~km}$ and a cost of $\$ 80$ million, which connects the offshore platforms in the Gulf of Mexico, was completed in 2010, as well as the STATOIL system in the North Sea in 2009 (Еремин, 2011).

According to (Huiyuna et al., 2019), in 1997 the first SCRAMS electronic hydraulic intelligent well system (Jingmei, 2008) developed by Halliburton and Beihai Petroleum Service Engineering Company was installed on the Saga Tension Leg Platform in Beihai (a district in the Guangxi Zhuang Autonomous Region of the PRC). Since then the technology of smart wells in the field of oil and gas development has begun to develop rapidly: over the first 10 years the number of production wells with smart systems has grown with an intensity of $27 \%$ per year, and more than a thousand production wells have been reasonably transformed. In the second decade large foreign oil and gas companies including the Shell Petroleum Company took into account the technical requirements for smart wells and traditional means of production. More than 300 producing wells were equipped with a complete intelligent system. The work (Huiyuna et al., 2019) also gives a tabular form of data summarized for a number of studies on individual fields in the world where smart systems with the names of the executing companies were used. Analysis and synthesis of literature data shows the active involvement of leading oil companies in the development and implementation of the "Intelligent Field" systems. Among the countries it should be noted the USA, Norway, Mexico, the countries of Africa, Latin America, Russia, Kazakhstan, etc. Practical examples from fields in the Gulf of Mexico, the North Sea, Saudi Arabia and Africa show how intelligent technologies can help increase production at lower cost, significantly reduce water production in production wells, assess the potential of new fields, etc. 
Summing up we note that in a review devoted to a very important area today, it is impossible to cover the whole variety of problems, to show the advantages and disadvantages of the system. It should be noted that in these systems great importance is attached to all issues related to the management of field development, well drilling, equipment and well protection. With the right and scientifically based approach to the construction of these systems, it is also possible to better identify anomalies and deviations from the operating ranges of parameter values during the implementation of technological solutions during drilling and production at early stages and to prevent them in a timely manner. In this case it is possible to better identify anomalies and deviations from the operating ranges of parameter values when implementing process solutions while drilling and producing at early stages and to prevent them in a timely manner. Thanks to "smart fields", it is possible to improve the quality of reservoir management, as a result of which an increase in production can be achieved also due to an improvement in the quality of control over reservoir properties.

In general, due to the above measures, it is possible to mitigate risks in the sphere of technology, industrial, environmental and occupational safety. Automation of processes allowed successful performance of operations to optimize production in remote access mode. This is one of the main advantages of a smart field, i.e. the fact that it minimizes problems and their solution time associated with the field location, distance and time. At the same time control limits are expanding from regional office (or offshore platform and drilling rig) to sensors installed on downhole or surface equipment and to mobile personnel equipped with modern devices and communications. In favor of the aforementioned evidence is the analysis performed in (Еремин, 2011). As can be seen from the experience accumulated by leading companies to date, smart technologies in the oil and gas industry put forward good opportunities that increase the efficiency of well drilling control and oil and gas reservoir management by saving time and energy in relation to the technologies and manpower used, given that the technology applied is economical for the area under consideration.

\section{REFERENCES}

Akhmetov D.A., Efendiyev G.M., Karazhanova M.K., Koylibaev B.N. Classification of hard-to-recover hydrocarbon reserves of Kazakhstan with the use of fuzzy clusteranalysis. 13th International Conference on theory and application of fuzzy systems and soft computing - ICAFS-

\section{Conclusion}

As the review of studies shows, a sufficient number of works on the development and improvement of «Smart Field» systems have been accumulated, and a number of interesting results have been obtained to date. Despite the recent development of the "smart field" concept in the oil and gas industry there are still problems associated with various kinds of uncertainties that arise when evaluating geological conditions, solving problems of facility classification, justifying and choosing criteria for making the right decisions when drilling and producing in relation to the conditions under consideration, etc. The features of a given field development history as well as the management of production and economic activities of an oil field are insufficiently studied when implementing the «Smart Field» systems.

Leading oil and gas companies are currently working on problems, trying to ensure highly efficient well drilling and oil and gas field development operations aimed at obtaining high technical and economic indicators providing environmental safety. Field intellectualization contributes to the improvement and optimization of drilling and oil production processes. In this regard, it is necessary to carry out a set of studies aimed at the scientific substantiation of the features of oil and gas companies management processes in the construction and implementation of the «Smart Field» system under objective conditions of increasing cost of hydrocarbon production in fields with hard-to-recover reserves.

Based on the results of recent studies a list of specialists required for the modern oil and gas industry can be prepared. The most demanded are the competencies that can be applied in any industry (Анализ данных и научный подход..., 2018). То successfully solve the problems associated with "smart fields", it is necessary to combine the efforts of experts in various fields, namely geologists, geophysicists, reservoir managers, drillers, programmers as well as economic and mathematical modeling, creation of automated control and decision-making systems. The methods considered in this review, when applied, can have a significant impact on the quality of various types of operations when constructing «Smart Field» systems, which in turn will save time, reduce risks and costs, increase efficiency and allow solving a large number of problems at various stages of «Smart Field» system design.

\section{ЛИТЕРАТУРА}

Akhmetov D.A., Efendiyev G.M., Karazhanova M.K., Koylibaev B.N. Classification of hard-to-recover hydrocarbon reserves of Kazakhstan with the use of fuzzy clusteranalysis. 13th International Conference on theory and application of fuzzy systems and soft computing - ICAFS- 
2018, Springer Nature Switzerland. Warsaw, Poland, 27-28 August 2018, pp. 865-872.

Bello O., Holzmann J., Yaqoob T., Teodoriu C. Application of artificial intelligence methods in drilling system design and operations: a review of the state of the art. Journal of Artificial Intelligence and Soft Computing Research, Vol. 5, No. 2, 2015, pp. 121-139.

Cuddy S.J., Glover P.W.J. The application of fuzzy logic and genetic algorithms to reservoir characterization and modeling. Soft Computing for Reservoir Characterization and Modeling, No. 1, 2002, pp. 219-241.

Data analysis and scientific approach: how new technologies are changing the oil sector. ITMO.NEWS, 2018, news.itmo.ru/ ru/startups_and_business/partnership/news/7491/ (in Russian).

Demarchuk V.V. Domestic and international experience in implementing "smart" field projects. Young scientist, No. 19, 2014a, pp. 295-297 (in Russian).

Demarchuk V.V. Prospects and areas for the implementation of "smart" oil and gas field projects. Young scientist, No. 19, 2014b, pp. 284-289 (in Russian).

Efendiyev G.M. Oil and gas technology during the fourth industrial revolution. In materials of the International scientificpractical conference: "The main trends in the development of energy and mechanics under the conditions of the fourth industrial revolution", dedicated to the 50th anniversary of the Faculty of oil, gas and mechanics. Taraz, Taraz University, 2019, pp. 5-9 (in Russian).

Efendiyev G., Mammadov P., Piriverdiyev I., Mammadov V. Estimation of the lost circulation rate using fuzzy clustering of geological objects by petrophysical properties. Visnyk of Taras Shevchenko National University of Kyiv, Geology, Vol. 2(81), 2018, pp. 28-33.

Efendiyev G.M., Mammadov P.Z., Piriverdiyev I.A. Modeling and evaluation of rock properties based on integrated logging while drilling with the use of statistical methods and fuzzy logic. 10th International conference on theory and application of soft computing, computing with words and perceptions ICSCCW-2019. Advances in intelligent systems and computing book series (AISC), Vol. 1095, 2019, pp. 503-511.

Efendiyev G.M., Mammadov P.Z., Piriverdiyev I.A., Mammadov V.N. Clustering of geological objects using FCM-algorithm and evaluation of the rate of lost circulation. Procedia computer science (Elsevier), Vol. 102, 2016, pp. 159-162.

Efendiyev G., Piriverdiyev I. Terminological uncertainties in oilfield theory, practice and decision-making. The 5th International conference on applied linguistics issues, Istanbul, Turkey, 22-23 October 2018, pp. 79-83.

Eryomin N.A. Management of the development of intelligent oil and gas fields. Textbook for universities in 2 books. Book 1. Russian State University of oil and gas named after I.M. Gubkin. Moscow, 2011, 200 p. (in Russian).

Huiyuna M., Chenggang Y., Liangliang D. et al. Review of intelligent well technology. Chinese Roots Global Impact, Petroleum, No. 14, 2019, https://www.sciencedirect.com/ science/article/pii/S2405656119301609

https://neftegaz.ru/news/politics/202118-kazakhstan-razvivaetproekt-tsifrovoe-mestorozhdenie/, 2018 (in Russian).

Jingmei W. Development trend of intelligent well technology in the next decade. Oil Forum, No. 2, 2008, pp. 32-34.

Kozlova D., Pigarev D. Digital oil production: tuning for the industry. VYGON Consulting, June 2018, https://vygon.consulting/ products/issue-1322/ (in Russian).

Kyrnaev D., Maslanov A., Karpov V. et al. Challenges and results in implementing a smart field concept to increase an operational and a developing efficiency at mature field AO RITEK case study. In: SPE Russian Petroleum Technology Conference, Moscow, Russia, 16-18 October 2017, https://www.onepetro.org/conference-paper/SPE-187773-MS.
2018, Springer Nature Switzerland. Warsaw, Poland, 27-28 August 2018, pp. 865-872.

Bello O., Holzmann J., Yaqoob T., Teodoriu C. Application of artificial intelligence methods in drilling system design and operations: a review of the state of the art. Journal of Artificial Intelligence and Soft Computing Research, Vol. 5, No. 2, 2015, pp. 121-139.

Cuddy S.J., Glover P.W.J. The application of fuzzy logic and genetic algorithms to reservoir characterization and modeling. Soft Computing for Reservoir Characterization and Modeling, No. 1, 2002, pp. 219-241.

Efendiyev G., Mammadov P., Piriverdiyev I., Mammadov V. Estimation of the lost circulation rate using fuzzy clustering of geological objects by petrophysical properties. Visnyk of Taras Shevchenko National University of Kyiv, Geology, Vol. 2(81), 2018, pp. 28-33.

Efendiyev G.M., Mammadov P.Z., Piriverdiyev I.A. Modeling and evaluation of rock properties based on integrated logging while drilling with the use of statistical methods and fuzzy logic. 10th International conference on theory and application of soft computing, computing with words and perceptions ICSCCW-2019. Advances in intelligent systems and computing book series (AISC), Vol. 1095, 2019, pp. 503-511.

Efendiyev G.M., Mammadov P.Z., Piriverdiyev I.A., Mammadov V.N. Clustering of geological objects using FCM-algorithm and evaluation of the rate of lost circulation. Procedia computer science (Elsevier), Vol. 102, 2016, pp. 159-162.

Efendiyev G., Piriverdiyev I. Terminological uncertainties in oilfield theory, practice and decision-making. The 5th International conference on applied linguistics issues, Istanbul, Turkey, 22-23 October 2018, pp. 79-83.

Huiyuna M., Chenggang Y., Liangliang D. et al. Review of intelligent well technology. Chinese Roots Global Impact, Petroleum, No. 14, 2019, https://www.sciencedirect.com/ science/article/pii/S2405656119301609

https://neftegaz.ru/news/politics/202118-kazakhstan-razvivaetproekt-tsifrovoe-mestorozhdenie/, 2018.

Jingmei W. Development trend of intelligent well technology in the next decade. Oil Forum, No. 2, 2008, pp. 32-34.

Kyrnaev D., Maslanov A., Karpov V. et al. Challenges and results in implementing a smart field concept to increase an operational and a developing efficiency at mature field AO RITEK case study. In: SPE Russian Petroleum Technology Conference, Moscow, Russia, 16-18 October 2017, https://www.onepetro.org/conference-paper/SPE-187773-MS.

Redutskiy Y. Conceptualization of smart solutions in oil and gas industry. The $7^{\text {th }}$ International conference on sustainable energy information technology. Procedia computer science, Vol. 109, 2017, pp. 745-753.

Rossi D.J., Gurpinar O., Nelson R., Jacobsen S. Discussion on integrating monitoring data into the reservoir management process. In materials of European Petroleum Conference. Paris, France, Society of Petroleum Engineers, 24-25 October 2000, https://www.onepetro.org/conference-paper/SPE-65150-MS.

Smart Wells - ROGTEC, 2014. https://rogtecmagazine.com/wpcontent/uploads/2014/10/083.pdf.

Temizel C., Canbaz C.H., Palabiyik Y. et al. A comprehensive review of smart/intelligent oilfield technologies and applications in the oil and gas industry. In: SPE Middle East oil and gas show and conference, Manama, Bahrain, March 2019, https://www.onepetro.org/conference-paper/SPE-195095-MS.

Анализ данных и научный подход: как новые технологии меняют нефтяной сектор, ITMO.NEWS, 2018, news.itmo.ru/ ru/startups_and_business/partnership/news/7491/.

Воробьев А.Е., Тчаро Х., Воробьев К.А. Цифровизация нефтяной промышленности: «интеллектуальный» нефтепромысел. Вестник Евразийской науки, Т. 10, №. 3, 2018, с.1-16. 
Lopukhov I. Smart systems in oilfields: examples. CONTROL ENGINEERING Russia, Vol. 68, No. 2, 2017, pp. 74-77 (in Russian).

Redutskiy Y. Conceptualization of smart solutions in oil and gas industry. The $7^{\text {th }}$ International conference on sustainable energy information technology. Procedia computer science, Vol. 109, 2017, pp. 745-753.

Rossi D.J., Gurpinar O., Nelson R., Jacobsen S. Discussion on integrating monitoring data into the reservoir management process. In materials of European Petroleum Conference. Paris, France, Society of Petroleum Engineers, 24-25 October 2000, https://www.onepetro.org/conference-paper/SPE65150-MS.

Smart well. 2015, https://neftegaz.ru/tech-library/burenie/ 142243 intellektualnaya-skvazhina/ (in Russian).

Smart Wells - ROGTEC, 2014, https://rogtecmagazine.com/wpcontent/uploads/2014/10/083.pdf.

Temizel C., Canbaz C.H., Palabiyik Y. et al. A comprehensive review of smart/intelligent oilfield technologies and applications in the oil and gas industry. In: SPE Middle East oil and gas show and conference, Manama, Bahrain, March 2019, https://www.onepetro.org/conference-paper/SPE195095-MS

Vorobyov A.E., Tcharo H., Vorobyov K.A. Digitalization of oil industry: "smart" oilfield. The Eurasian Scientific Journal, Vol. 10, No. 3, 2018, p. 1-16 (in Russian).

Zabrodin O.Yu., Bortnikov A.E. "Smart field" concept, theory and reality: prospective developments and expectations. Engineering Practice, No. 1, 2018, https://glavteh.ru/ интеллектуальное-месторождение/ (in Russian).
Демарчук В.В. Отечественный и международный опыт реализации проектов «интеллектуальных» месторождений. Молодой ученый, No. 19, 2014a, с. 295-297.

Демарчук В.В. Перспективы и направления реализации проектов «интеллектуальных» месторождений нефти и газа. Молодой ученый, No. 19, 20146, с. 284-289.

Ерёмин Н.А. Управление разработкой интеллектуальных месторождений нефти и газа. Учебное пособие для вузов в 2 кн. Кн. 1. РГУ нефти и газа имени И.М. Губкина. Москва, 2011, 200 с.

Забродин О.Ю., Бортников А.Е. Концепция «интеллектуальное месторождение», теория и реальность: перспективные разработки и ожидания. Инженерная практика, No. 1, 2018, https://glavteh.ru/ интеллектуальное-месторождение/.

Интеллектуальная скважина, 2015, https://neftegaz.ru/techlibrary/burenie/142243-intellektualnaya-skvazhina/.

Козлова Д., Пигарев Д. Цифровая добыча нефти: тюнинг для отрасли. VYGON Consulting, июнь 2018, 61 с., https://vygon.consulting/products/issue-1322/.

Лопухов И. Интеллектуальные системы на нефтяных месторождениях: примеры. CONTROL ENGINEERING Россия, Т. 68, No. 2, 2017, с. 74-77.

Эфендиев Г.М. Нефтегазовые технологии в период четвертой промышленной революции. В материалах Международной научно-практической конференции «Основные тенденции развития энергетики и механики в условиях четвертой промышленной революции», посвященной 50-летию факультета «Нефти, газа и механики». Тараз, Тараз университеті, 2019, с. 5-9.

\title{
СОВРЕМЕННОЕ СОСТОЯНИЕ И ПЕРСПЕКТИВЫ РАЗВИТИЯ ТЕХНОЛОГИЙ «ИНТЕЛЛЕКТУАЛЬНОЕ МЕСТОРОЖДЕНИЕ»
}

\author{
Исаев Р.А. \\ $O O O \ll S O C A R A Q S »$ \\ AZ1052, Азербайджанская Республика, г. Баку, ул. Ахмеда Раджабли-2, 10: risayev@ socar-aqs.com
}

Pезюме. В настоящей статье приводится краткий анализ современного состояния проблемы создания научных основ концепции «интеллектуальное месторождение», которое рассматривается в качестве системы. Отмечается, что реализация задач согласно данной концепции производится в четыре этапа. На примерах опыта различных компаний приводятся результаты функционирования отмеченной системы. С точки зрения обеспечения в состав системы «интеллектуальное месторождение» в качестве подсистем главным образом входят три системы: информационного обеспечения, математического и программного обеспечения и организационного обеспечения. Полученная информация позволяет принимать оперативные и правильные управленческие решения, обеспечивать эффективное планирование и внедрение геолого-технических мероприятий, ремонтно-профилактического обслуживания оборудования.

В целом главное место в системе занимает принятие решений. При этом в большинстве своем решения принимаются в условиях неопределенности. Поэтому разработка научных основ системы включает также анализ неопределенностей, которые бывают разного характера. Показана необходимость комплекса исследований, направленных на научное обоснование особенностей процессов управления нефтегазодобывающими предприятиями при построении и внедрении системы «интеллектуальное месторождение» в объективных условиях роста себестоимости добычи углеводородов на месторождениях с трудноизвлекаемыми запасами.

Предлагается сформировать список специалистов, необходимых в современной нефтегазовой отрасли. Отмечено, что наиболее востребованными являются компетенции, которые могут быть применимы в любой отрасли. Для успешного решения задач, связанных с «интеллектуальными месторождениями», необходимо объединение усилий специалистов разного профиля, а именно: геологов, геофизиков, разработчиков, буровиков, программистов, а также работающих в сфере экономико-математического моделирования, создания систем автоматизированного управления и принятия решений.

Ключевые слова: интеллектуальное месторождение, информационное обеспечение, математическое и программное обеспечение, организационное обеспечение, принятие решений 


\title{
“İNTELLEKTUAL YATAQ” TEXNOLOGIYYLARININ MÜASİR VəZIYYYTİ Və İNKİŞA PERSPEKTIVLORİ
}

\author{
İsayev R.ə. \\ "SOCAR AQŞ" Mahdud Masuliyyatli Camiyyati \\ AZ1075, Azarbaycan Respublikası, Bakı şəh., Ә.Racəbli-2 küçasi, 10: risayev@socar-aqs.com
}

Xülasə. Təqdim olunmuş məqalədə "intellektual yataq" konsepsiyasının elmi əsaslarının yaradılması probleminin müasir vəziyyətinin icmalı verilir. Qeyd olunur ki, həmin konsepsiyaya əsasən məsələlərin həllinin həyata keçirilməsi dörd mərhələdə aparılır. Qeyd olunmuş sistemin işi müxtəlif şirkətlərin fəaliyyəti timsalında göstərilir. "İntellektual yataq" sistemi tərkibinə təminat nöqteyunəzərindən altsistem kimi üç sistem daxil olur: informasiya təminatı, riyazi və proqram təminatı, təşkilati təminat. Oldə edilmiş informasiya operativ surətdə düzgün idarəedici qərarların qəbulu üçün imkan yaradır, geoloji-texniki tədbirlərin seçilməsi, eləcədə avadanlığın təmir-profilaktik xidməti yollarının planlaşdırılması və tətbiqini təmin edir. Burada əsas yeri qərarların qəbulu tutur. Qeyd olunur ki, adətən qərarlar qeyri müəyyənlik şəraitində qəbul olunur. Bu baxımdan sistemin qurulması zamanı adətən müxtəlif xüsusiyyətlərə malik olan qeyri müəyyənliklərin araşdırılması tövsiyyə olunur.

İcmal nəticəsində, çətinliklə çıxarıla bilən ehtiyat yataqlarında karbohidrogen hasilatının maya dəyərinin artmasının obyektiv şəraitində "intellektual yataq" sisteminin təşkili və tətbiqi zamanı neft-qazçıxarma müəssisələrinin idarə olunması prosesinin xüsusiyyətlərinin əsaslandırılmasına yönəldilmiş kompleks tədqiqatlarının aparılmasının zəruriliyi göstərilir, bununla əlaqədar müvafiq tədbirlər qeyd olunur. Belə ki, məqalədə müasir neft-qaz sahəsi üçün zəruri olan mütəxəssislərin siyahisinin tərtib edilməsi təklif olunur. Qeyd olunur ki, ən çox tələb olunan mütəxəssislər istənilən sahədə işləmək bacarığına malik mütəxəssislərdir. "İntellektual yataq" konsepsiyası ilə əlaqədar məsələlərin müvəffəqiyyətlə həlli üçün müxtəlif ixtisaslı mütəxəssislərin qüvvələrinin birləşməsi ilə işçi kollektiv təşkil olunmalıdır, belə ki, bura aşağıdakı ixtisaslara malik mütəxəssislərin daxil olması nəzərdə tutulmalıdır: geoloqlar, geofiziklər, qazmaçılar, işlənmə üzrə mütəxəssislər, proqramlaşdırıcılar, riyazi-iqtisadi modelləşdirilmə, avtomatlaşdırılmış idarəetmə sistemləri və qərarların qəbulu üzrə mütəxəssislər.

Açar sözlor: intellektual yataq, informasiya təminatı, riyazi və proqram təminatı, təşkilati təminat, qərar qəbulu 